\title{
Demand Forecasting of Trading Companies Based on Time Sequence
}

\author{
Fanda Layla Sari* \\ Magister of Accounting Information System \\ State Polytechnic of Malang \\ Malang, Indonesia \\ *Fandalayla91@gmail.com
}

\begin{abstract}
CV Lancar Jaya Sakti is a trading company that has not applied forecasting methods in procurement and longterm inventory analysis, so there is no certainty or basis for making requests for goods from suppliers. The purpose of this study is to describe how the demand forecasting method can be applied as a basis for making decisions to minimize the risks that will occur in the future. The technique used in this research is descriptive with quantitative forecasting. The results showed a decrease in sales demands in the forecast period of 2021. This is mostly due to unpredictable external factors such as the Covid-19 pandemic and government policy. The advice given is to optimize the existing resources using the SWOT AHP (Analytical Hierarchy Process) method. The contribution of this research is to prove how the implementation of demand forecasting can solve problems that result in a company's financial losses. The limitation of this research is the sales flow of CV Lancar Jaya Sakti.
\end{abstract}

Keywords—demand forecasting, time sequence, risk

\section{INTRODUCTION}

One of the causes of risk is the result of the uncertainty that cannot be predicted in the future either in an organization or the mechanism of a particular system. In a business entity, the kind of risk that will arise is supply chain risk. To solve this problem, a business entity needs a system that can be regulated. Supply Risk Management (SRM) is a system in an organization that uses qualitative and quantitative methods to identify, evaluate, and monitor the activities that impact inventory management [1]. Regarding inventory control, several elements contribute to the flow of inventory control, namely 1) suppliers, 2) factories (manufacturing supplies and product procurement), 3) distribution centers, 4) partner outlets, and 5) consumers [2].

One solution to solving problems related to inventory is to use demand forecasting, which can help analyze how inventory fluctuations occur in a company using quantitative methods (time sequence and moving average). Based on the results of the fluctuation diagrams made in the end, it can conclude how to forecast terms based on historical data and policies that have been made to consider external conditions outside the company
[3]. Using demand forecasting analysis can help analyze the continuity and optimal conditions that the company has to increase time effectiveness and cost efficiency to achieve optimal results [4].

Based on this background, the purpose of writing this article is to identify and analyze how to forecast inventory using demand forecasting (time sequence and moving average), which can be used by the distributor to analyze the fluctuations of market demands and inventory quantity as a form of optimization effectiveness and performance efficiency of a system. In this case, we will discuss in the company CV Lancar Jaya Sakti, a distributor of bottled drinking water in Malang East Java. So far, CV Lancar Jaya Sakti has not applied any forecasting method to identify long-term inventories. This risk is causing losses both in financial and managerial aspects due to the risk of not fulfilling consumer demand even the threat of overstock with high inventory treatment costs.

\section{LITERATURE REVIEW}

\section{A. Demand Forecasting}

Demand forecasting is useful for several industrial sectors, especially in identifying investment levels, market competition, potential product distribution in the marketing aspect, etc. Different studies are comparing various methods of demand forecasting, such as research conducted by Boylan in 2004, which discusses the comparison of forecasting method variations with the SKU (Stock keeping units) method, Boylan in 2005 which discusses the comparison of the single exponential smoothing method, and Croston's method, and Boylan in 2006 which compared the moving weighted average process with the Croston method [5]. Based on the results of research conducted by Boylan and Croston in the current year, it is proven that the weighted moving average method is the method with the most accurate level of accuracy when compared to the previous methods.

In general demand forecasting, it can be concluded that a long-term forecasting concept has the aim of identifying fluctuations or cycles related to the forecast period, which are then used as a basis for determining probability and making 
decisions. Demand forecasting is essential to achieve optimal company performance, especially in the aspect of supply flows.

\section{B. Time Sequence}

Time sequence or time series is a method for identifying and visualizing a range of data within a specific time or interval to describe forecast plots and data schemes, which can then use as a medium for analyzing a long-term condition or cycle that occurs through historical data [6]. Forecasting based on time series or time sequences consists of 1) linear trend, 2) quadratic regression, 3) exponential, and 4) cyclic [7].

\section{Forecasting Concept}

Forecasting is an activity carried out to identify needs that occur in the future by using empirical measures to implement preparation for meeting needs or requests according to the predictions made [8]. In practice, forecasting is done by identifying objectives, making plans, selecting forecasting methods following the data, calculating parameters, calculating standard deviations, and implementing forecast verification [9].

The methods that can be used to analyze data are as follows [10]:

1) Exponential smoothing: It is a method of forecasting using moving averages and exponential declining weighting with the following formula [7]:

$$
\mathrm{F}_{\mathrm{t}+1}=\alpha \mathrm{X}_{\mathrm{t}}+(1-\alpha) \mathrm{F}_{\mathrm{t}}
$$

Information: $\mathrm{F}_{\mathrm{t}+1}=$ The value of the next forecast, $\alpha=$ Parameters with values 0 to $1, X_{t}=$ actual data for the current period, and $\mathrm{Ft}=$ the value of the current forecast.

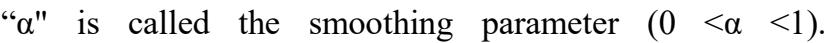
Exponentially smoothed sequences can use as nonparametric trends. In the movement obtained through the exponential smoothing method, whenever new data is available, the direction will automatically update according to the latest observations.

2) Moving average: The next method that is often used is the moving average (MA) method, in which the moving average trend value at " $\mathrm{t}$ " is obtained as the (weighted) average of the series set values taken around " $t$ ". Usually, the weights charged are the same-forecasting based on time series divided into a linear trend, quadratic regression, exponential, and cyclic.

In the formula, the moving average can be visualized using the following formula [11]:

$$
\operatorname{Ma}(t)=(1 / 4)[\mathrm{x}(t)+\mathrm{x}(t-1)+\mathrm{x}(t-2)+\mathrm{x}(t-3)]
$$

In the trend, the options carried out is using the Ms. application. Excel, the Moving Average choice is based on a uniformly weighted average with the user setting the Period parameter, which is the number of terms averaged.

\section{Measuring the Accuracy of Forecasting Results}

Measurements are intended to show how far the known data can produce a suitable forecasting method through the commonly used indicators [5], namely 1) MAD (Mean Absolute Deviation), which identifies the gap between the forecast and actual demand, 2) MSE (Mean Square Error) by adding squares all forecast errors in each period and divide by the number of periods mathematically, 3) MAPE (Mean Absolute Percentage Error) using the absolute error in each period if divided by the actual observed value for a certain period [12].

\section{E. Forecasting Verification and Control}

The most crucial stage in forecasting is the implementation of verification of the accuracy and validity of the methods and data used so that the results of the forecasting can reflect the real data and reflect past data [13]. Validation and control of forecasting are carried out by ensuring that the data used from the beginning of the study is reliable and can be used in the future to minimize doubts about the validity of the forecasting method used. The simplest form, the technique used to reduce errors, is to visualize existing data using a Moving range chart similar to a quality control map [14].

\section{RESEARCH METHODS}

This type of research is a descriptive study with quantitative forecasting that reveals empirically the use of numbers to predict conditions that will occur in the future [9] which then based on the data that has processed, conclusions can be drawn as a basis for decision making for the entity that uses. This study is limited to only focusing on forecasting sales, which will then be correlated with the amount of inventory needed.

The variable in this study is the sales of CV Lancar Jaya Sakti, which is a trading company with a supplier of manufacturing companies including 1) PT Indomarco Adi Prima, 2) PT Padma Tirta Wisesa, and 3) PT Cipta Niaga Semesta. The company, which is located in Pakis District, Malang Regency, is a company with a CV status with the name "CV Lancar Jaya Sakti". The market absorption is divided into several parts, which include: 1) SO (Special outlites), 2) Wholesale, 3) Sub Wholesale, and 4) Canvas (user unit).

This study focuses on the application and analysis of future sales forecasting as a basis for the procurement of CV Lancar Jaya Sakri's inventory from a manufacturing company (supplier). Long-term analysis and forecasting activities are based on past data with mathematical models. The research sample used in this research is data in the current period of 2018 (January-December), 2019 (January-December), and 2020 (January-October), which is then used as the basis for forecasting sales in 2021 (January-December). The focus of the data required is secondary data in the form of travel documents (procurement of supplies) for the current period, administrative requirements, and financial reports for the current period (to determine the turnover range and track record of financial policies undertaken). 
The analysis step in this research is carried out by 1) Identifying the time series in the data, 2) Analyzing using an exponential smoothing forecast and using a moving average, 3 ) Calculating the accuracy of the forecasting model, 4) Comparing the best forecasting analysis, 5) Analyzing the financial policies carried out, 6) Analyzing non-financial policies, 7) Making conclusions on the results of the forecasting process.

TABLE I. TOTAL SALES OF CV LANCAR JAYA SAKTI FROM JANUARY 2019 TO OCTOBER 2020

\begin{tabular}{|l|l|l|l|}
\hline & \multicolumn{3}{|c|}{ Sales (Year) } \\
\hline \multicolumn{1}{|c|}{ Month } & \multicolumn{1}{|c|}{$\mathbf{2 0 1 8}$} & \multicolumn{1}{c|}{$\mathbf{2 0 1 9}$} & $\mathbf{2 0 2 0}$ \\
\hline January & 9806 & 9555 & 8511 \\
\hline February & 8500 & 9883 & 8303 \\
\hline March & 10661 & 13332 & 7986 \\
\hline April & 15217 & 11570 & 2368 \\
\hline May & 16013 & 12464 & 3855 \\
\hline June & 7794 & 10754 & 3725 \\
\hline July & 12675 & 10052 & 4093 \\
\hline August & 13887 & 14107 & 5243 \\
\hline September & 11669 & 10063 & 4510 \\
\hline October & 11073 & 10996 & 3127 \\
\hline November & 12350 & 12681 & \\
\hline December & 11689 & 10883 & \\
\hline
\end{tabular}

Resource: CV Lancar Jaya Sakti, Malang, 2020.

Data collection techniques used are 1) interviews (in order to obtain information in accordance with the problem through interviews with the owner of CV Lancar Jaya Sakti), 2) documentation techniques (by making direct observations about company sales reports based on documents held), 3) observation (making direct observations of objects which then record information during research within the company), 4) literature study (by examining appropriate theories and analyzing relevant previous research through journals, books, and other literature)

\section{RESULTS AND DISCUSSION}

Based on the data processing carried out, the CV Lancar Jaya Sakti request data pattern in Figure 1,

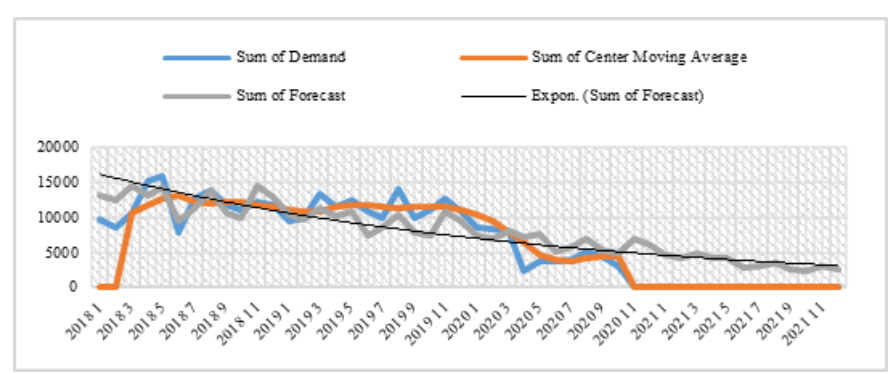

Fig. 1. The data pattern of CV Lancar Jaya Sakti's request.

In the time series component, there is a variation which in the case of CV Lancar Jaya Sakti is a cyclic variation which is visualized in Figure 1, which consists of elements 1) Prosperity, 2) Depression, 3) Contraction, 4) Recovery as to form a cycle of repeating time series. Based on these data, from
2018 to 2019 there was sales stability at CV Lancar Jaya Sakti, but there was a drastic decline in 2020. This happened due to external factors affecting the market, so that the goods received by CV Lancar Jaya Sakti could not be absorbed by the market correctly.

From this figure, the standard summary generated through regression data processing is as follows:

TABLE II. SUMMARY OF REGRESSION TESTS

\begin{tabular}{|l|l|}
\hline \multicolumn{2}{|c|}{ Regression Statistics } \\
\hline Multiple R & 0.7460 \\
\hline R Square & 0.5565 \\
\hline Adjusted R Square & 0.5422 \\
\hline Standard Error & 0.2412 \\
\hline Observations & 33 \\
\hline \multicolumn{2}{|c|}{ Source: Data processed, 2020.}
\end{tabular}

With details in the summary of the regression test (table 2), it is concluded that the data being tested are reasonable and good data knowing the low level of standard error and the number of $\mathrm{R}$ that is close to 1 . Followed by testing the accuracy of the forecasting results, resulting in a summary table 3 as follows:

TABLE III. SUMMARY OF TESTING DATA

\begin{tabular}{|l|l|}
\hline \multicolumn{1}{|c|}{ Type of Tools } & \multicolumn{1}{c|}{ Result } \\
\hline MAD & 1857 \\
\hline MSE & $6,206,782$ \\
\hline MAPE & $27 \%$ \\
\hline
\end{tabular}

Resource: Data Processed, 2020

A summary of the data testing carried out can be continued by analyzing the sales forecast results at CV Lancar Jaya Sakti, which are used to forecast sales in 2021 as a basis for procuring goods, which in this case is taken from PT Indomarco. The reason for choosing an analysis in the form of a supplier to PT Indomarco is knowing the stability of demand for goods and the existence of standardized prices so that the accuracy of the data can be considered forecasting. After performing the analysis using a moving average and time-sequence analysis, the resulting forecast data is as follows:

TABLE IV. SALES ForeCASTING RESUlTS CV LANCAR JAYA SAKTI JANUARY-DECEMBER 202

\begin{tabular}{|l|l|l|}
\hline \multicolumn{1}{|c|}{ Year } & Month & Demand \\
\hline 2021 & 1 & 6641 \\
\hline 2021 & 2 & 5678 \\
\hline 2021 & 3 & 4419 \\
\hline 2021 & 4 & 3986 \\
\hline 2021 & 5 & 4483 \\
\hline 2021 & 6 & 3820 \\
\hline 2021 & 7 & 3940 \\
\hline 2021 & 8 & 2510 \\
\hline 2021 & 9 & 2776 \\
\hline 2021 & 10 & 3136 \\
\hline 2021 & 11 & 2235 \\
\hline 2021 & 12 & 1915 \\
\hline
\end{tabular}

Resource: data processed, 2020 
Based on the resulting data (table 4), it describes that there is a risk of decreasing demand that will occur in 2021. This data degradation occurs if the conditions that affect the decline in data in 2020 continue in 2021. According to observations, it found that this decline occurred due to a capable pandemic condition. Freeze community activities, especially in the field of education, knowing that the most significant consumer for CV. Lancar Jaya Sakti is a partner with educational institutions, which is 2020 to 2021, experienced a decrease in educational activities carried out in institutional areas to reduce mass consumption [15]. Pandemic is an essential factor in decreasing market demand due to low consumption and economic turnover in society [16].

Through interviews conducted with the owner of $\mathrm{CV}$ Lancar Jaya Sakti, the reduction in consumer demand is a challenge that requires cohesiveness between suppliers and $\mathrm{CV}$ Lancar Jaya Sakti, so there is the support provided in the form of 1) promo programs, 2) sponsorships, and 3) bonuses regularly. As a form of motivation and stimulus to attract consumer interest. Besides, to compensate for the burden that comes out of the bonus given, CV Lancar Jaya Sakti is doing 1) by cutting the standard operating procedure for sales on $\mathrm{SO}$ (special outlite) by applying the just in time method and Free onboard shipping point, 2) conducting regular cooperation with wholesale shops and sub wholesalers by maintaining commitment and loyalty.

\section{CONCLUSION AND SUGgestions}

Knowing the conditions currently being experienced by $\mathrm{CV}$ Lancar Jaya Sakti, based on forecasting data that has decreased in the current year, especially for products supplied by PT Indomarco, the strategy carried out during external conditions (Covid-19 Pandemic) is to carry out a survival strategy. The survival strategy carried out by CV Lancar Jaya Sakti is by 1) using a partnership program with suppliers (PT Indomarco), 2) differentiating products to reduce the risk of financial loss, 3 ) expanding markets and relationships so as to develop the potential for market absorption based on the several research has been able to minimize the risks and losses resulting from instability in market conditions and external companies [17].

Suggestions are given to minimize long-term risks as well as reduce the rate of decline in demand due to unstable conditions, which can be done by analyzing and optimizing the resources owned and minimizing other risks that may arise through the several marketing explores such as SWOT (Strength, weakness, opportunity, and threat) supported by using the AHP (Analytical Hierarchy Process) method [18]. This method can ultimately provide options related to problemsolving that will occur at CV Lancar Jaya Sakti.

Suggestions for the next researcher are to design a structured, effective and efficient system that can be used as a tool in implementing the demand forecasting process at $\mathrm{CV}$ Lancar Jaya Sakti.

\section{REFERENCES}

[1] J. Pflieger, M. Fischer, T. Kupfer, and P. Eyerer, "The contribution of life cycle assessment to global sustainability reporting of organizations," Manag Environ Qual An Int J, vol. 16, pp. 167-79, 2005.

[2] L. Aburto and R. Weber, "Improved supply chain management based on hybrid demand forecasts," Appl Soft Comput J, vol. 7, pp. 136-44, 2007.

[3] H. Kawamuran and E. Kuo, "Inventory Management Based on Demand Forecasting Using Ryokan's Beer Sales Data," Innov Supply Chain Manag, vol. 9, pp. 127-35, 2015.

[4] W.H. Ip, S.L. Chan, and C.Y. Lam, "Modeling supply chain performance and stability," Ind Manag Data Syst, vol. 111, pp. 1332-54, 2011.

[5] A.A. Syntetos and J.E. Boylan, "On the stock control performance of intermittent demand estimators," Int J Prod Econ, vol. 103, pp. 36-47, 2006.

[6] D. Montgomery and K. Jennings, Introduction to Time Series Analysis and Forecasting. United States of America: Wiley, 2008.

[7] W.A. Marlina, S.N.E. Susiana, and F.A. Ahmad, "Forecasting technique using time sequence: model penentuan volume produksi Sanjai di UKM Rina Payakumbuh,” J Manaj, vol. 9, p. 187, 2018.

[8] S. Van der Auweraer, R.N. Boute, and A.A. Syntetos, "Forecasting spare part demand with installed base information: A review," Int J Forecast," vol. 35, pp. 181-96, 2019.

[9] G.O. Kaya and O.F. Demirel, "Parameter optimization of intermittent demand forecasting by using spreadsheet," Kybernetes, vol. 44, pp. 57687, 2015.

[10] M.A. Canela, I. Alegre, and A. Ibarra, "Quantitative Methods for Management," Quant Methods Manag, pp. 111-9, 2019.

[11] N. Singh, S.J. Olasky, K.S. Cluff, F. William, and F.J. Welch, "Supply chain demand forecasting and planning," vol. 2, p. 21, 2001.

[12] I.L.P. Navalina, N.I. Riwajanti, S. Sulistyono, and L. Djajanto, "Forecasting Produksi Perikanan Laut Yang Dijual Di Tpi (Ton) Dengan Metode Single Exponential Smoothing," Media Mahard, vol. 18, p. 206, 2020.

[13] S. Hsieh and M.S. Wu, "Demand and cost forecast error sensitivity analyses in aggregate production planning by possibilistic linear programming models," J Intell Manuf, vol. 11, pp. 355-64, 2000.

[14] D. Radson, "The moving-range chart and autocorrelated processes," Commun Stat - Theory Methods, vol. 26, pp. 2113-27, 1997.

[15] N.B. Argaheni, "Sistematik Review: Dampak Perkuliahan Daring Saat Pandemi COVID-19 Terhadap Mahasiswa Indonesia," PLACENTUM J Ilm Kesehat Dan Apl, vol. 8, p. 99, 2020.

[16] R.N. Azimah, I.N. Khasanah, R. Pratama, Z. Azizah, W Febriantoro, and S.R.S. Purnomo, “Analisis Dampak Covid-19 Terhadap Sosial Ekonomi Pedagang Di Pasar Klaten Dan Wonogiri,” EMPATI J Ilmu Kesejaht Sos, vol. 9, pp. 59-68, 2020.

[17] I. Sari, H. Riniwati, and N. Harahab, "Strategi Pemasaran Dalam Meningkatkan Volume Penjualan Pada Pt Hatni (Hasil Alam Tani Nelayan Indonesia) Di Desa Tlogosadang Kecamatan Paciran Kabupaten Lamongan Jawa Timur," ECSOFiM J Fish Mar Socioecon, vol. 3, 2015.

[18] Hm.G.B. Narto, "Penguatan Strategi Pemasaran Pudak Di Tengah Pandemi Covid-19 Untuk Meningkatkan Keunggulan,” J INTECH Tek Ind, vol. 6, pp. 48-54, 2020. 